\title{
ANALYSIS OF INTEGRATION AND PRICE EFFICIENCY: A CASE OF INDONESIAN COCOA BEANS EXPORT MARKET
}

\author{
Imama Nurus Izaati ${ }^{1 *}$, Ratya Anindita ${ }^{2}$, Sujarwo \\ ${ }^{1}$ Postgraduate Progam Faculty of Agricultural Economics, University of Brawijaya, Indonesia \\ ${ }^{2}$ Departement of Socioeconomics Faculty of Agricultural Economics, University of Brawijaya, Indonesia \\ *corresponding author:ima4m401@gmail.com
}

\begin{abstract}
In international trade, two markets are spatially integrated when the price of one commodity traded continuously and has the same price movement after adjusting the exchange rate and transaction cost. This condition indicates that price efficiency because information on price is well spread, so no participant of market can manipulate the price. Price movement of Indonesian cocoa beans has different movements with price of world market and importing countries. This indicates no price transmission, which means there is price discrepancy of Indonesia with world market and importing countries. This study examined degree of integration and price efficiency of Indonesia cocoa beans with world market and importing countries. Integration analysis using Cointegration Johansen approach, Vector Autoregression (VAR)/Vector Error Correction Model (VECM) and price efficiency analysis using the Generalized Autoregeressive Conditional Heteroscedasticity (GARCH) approach. The results showed that the price of Indonesian cocoa beans integrates long term with the price of cocoa beans in the world market (New York Board of Trade) and India. In the short term price of Indonesian cocoa beans integrated with the price of cocoa beans in Malaysia. Among the prices of Indonesian cocoa beans with USA does not happen both long-term and short-term integration. The price of Indonesian cocoa beans in the spot market of Makassar is included in the efficient market category of weak forms, where the current price reflects a set of pricing information in the past.
\end{abstract}

Keywords: Indonesian cocoa beans; Market integration; Price efficiency; Johansen cointegration; VAR; VECM; GARCH

http://dx.doi.org/10.21776/ub.agrise.2020.020.2.9

Received 30 July 2019

Accepted 11 April 2020

Available online 31 April 2020

\section{INTRODUCTION}

World cocoa consumption per capita currently reaches $0.59 \mathrm{~kg}$, estimated each year increase by $4 \%$. Increasing world consumption of cocoa should be balanced with availability of cocoa beans, one of world cocoa producers is Indonesia. Indonesia accounts for $15 \%$ of world cocoa needs and occupies third position of cocoa producers after Ivory Coast and Ghana (ICCO, 2014). Fluctuations in export volume of Indonesian cocoa beans caused the availability of cocoa beans in world market. This condition shows shock of supply cocoa beans

in world market, which can cause the fluctuation price of cocoa beans in world market. Fluctuations world price of cocoa beans, causing producers in Indonesian difficult predicting price, gains or possible losses are received (Ariyoso, 2010).

Trading central of Indonesia cocoa beans located in Makassar spot market. During this price determination of Indonesian cocoa beans in the market spot Makassar refers to the price of cocoa beans in New York Board of Trade as the world cocoa trade center (Ariyoso, 2010). In determining the expected price of cocoa beans price change in the world market can be quickly responded by all market participants, so there is a price transmission

CITATION: Izaati I., N., Anindita R., Sujarwo. (2020). Analysis of Integration and Price Efficiency: a Case of Indonesian Cocoa Beans Export Market. Agricultural Socio-Economics Journal, 20(2), 167-178

DOI: http://dx.doi.org/10.21776/ub.agrise.2020.020.2.9 
from the market of reference to the follower market and price movements in both markets will be the same. Price fluctuations or uncertainty are often utilized by traders who have more information to manipulate prices, so there is no transmission of prices from the consumer market to the manufacturer's market (Awal et al, 2009).

Level of price movements of one product marketed in different regions will have the same price movements as the price transmission form indicate that the markets are integrated (Flacker and Goodwin, 2001). The price movements of Indonesian cocoa beans have different price movements with the world market and importing countries. The difference in the price of Indonesian cocoa beans with Indonesian cocoa consumers is around US $\$ 0.5$ up to US $\$ 1.6$ (UNComtrade, 2017). Price discrepancy between Indonesia as producers and world market (New York Board of Trade), USA, Malaysia and India as consumers of Indonesian cocoa beans indicates no price transmission from the consumer market to producers market. The absence of price transmissions indicates that the markets are not interrelated or integrated. Market not integrated is due to several factors i.e far-of market distance, small volume of trade, inadequate of information facilities and marketing infrastructure, government policies, political instability, and a strong specific markets (Okoronkwo et al, 2018).

Price transmission shows well-transmitted price change information. Lence and Falk (2005) stated that efficient markets occur when market prices can reflect complete accurate and relevant information to maintain price stability. In case of price fluctuations due to the absence of price transmission will harm the Indonesian cocoa producers, because it must be faced with the risk of price uncertainty and allows the party to make an irrational profit. Market participants who are difficult to predict prices due to price variations cause the inefficient market (Bernal et al, 2003). Price predictability in the market is seen using a weak form market efficiency approach, where the current price reflects the price information in the past (Fama, 1970). The purpose in this research is to analysis level of integration of Indonesian cocoa beans with importing countries (USA, Malaysia, and India), analysis level of price integration of Indonesian cocoa beans with the world market (New York Board of Trade), and analysis price efficiency of Indonesian cocoa beans in spot market Makassar.

\section{RESEARCH METHODS}

Data collection method in this research is using secondary data time series monthly price of Indonesia cocoa beans in the spot market Makassar, price of cocoa beans in world market (New York Board of Trade), price of cocoa beans in USA, price of cocoa beans in Malaysia, and price of cocoa beans in India period 2013-2017. Source of data in this research are Central Statistical Agency, International Cocoa Organization (ICCO), Indonesia Cocoa Association (Askindo), and United Nation Comtrade.

Analysis of level integration between Indonesia cocoa beans with New York board of trade and importing countries using VAR/VECM model approach. The formation phase of VAR/VECM follow:

\section{a. Stationarity Test}

Using tme series data is generally nonstationary, allowing the result of the estimation parameter is spurious regression. If the result of spurious regression interpreted will give incorrect results and affect the error of policy formulation (Widarjono, 2013). Stationary data is required in analysis of time series data to minimize error estimation of model. All variables in this research was tested stationary using Augmented DickeyFuller (ADF) root test. The station test is done at level I (0), if the data has not been stationary then the test is done in the first difference I (1). The $\mathrm{ADF}$ test formulation in this research follows:

$\Delta P_{t}=\alpha_{0}+\gamma P_{t-1}+\beta_{i} \sum_{j=1}^{n} \Delta P_{t-1}+\varepsilon_{t}$

where:

$\mathrm{P}_{t}$ : price of Indonesia cocoa beans in every market at period $\mathrm{t}(\mathrm{US} \$ / \mathrm{Kg})$

$P_{t}$ : price of Indonesia cocoa beans in every market at period $\mathrm{t}-1$ (US $\$ / \mathrm{Kg})$

$\Delta \mathrm{P}_{\mathrm{t}}: \mathrm{P}_{\mathrm{t}}-\mathrm{P}_{\mathrm{t}-1}$

$\Delta \mathrm{P}_{\mathrm{t}-1}: \mathrm{P}_{\mathrm{t}-1}-\mathrm{P}_{(\mathrm{t}-1)-1}$

$\mathrm{N}$ : total lag

$\alpha_{0} \quad$ : intercept

$\beta_{i}, \gamma:$ Coefficient parameter

$\varepsilon_{\mathrm{t}} \quad:$ error term

Hypothesis Testing:

$H_{0}: \gamma=0$ (data time series is not stationary)

$H_{1}: \gamma<0$ (data time series is stationary)

Rules of testing:

1) If $\mathrm{ADF}_{\text {statistic }}>\mathrm{ADF}_{\text {critis }}$, reject $\mathrm{H}_{0}$ is mean that data time series does not contain unit root (stationary data) 
2) If $\mathrm{ADF}_{\text {statistic }}<\mathrm{ADF}_{\text {critis }}$, accept $\mathrm{H}_{0}$ is mean that data time series contain unit root (non-stationary data)

b. Optimal Lag Determination

Optimal of lag length determination in the VAR model is crucial to see the impact of each variable to other variables in model. Optimal lag use is intended to allow the residual between variables in the VAR equation to be free of normality and autocorrelation issues (Widarjono, 2013). There are several criteria used to determine the optimal lag length: Schwartz Information Criteria (SIC), Akaike Information Criteria (AIC), Likelihood Ratio (LR), Hanna-Quinn Criteria (HQ), and Final Prediction Error (FPE). In this research, determination of optimal lag length using Akaike Information Criteria (AIC).

\section{c. Cointegration Test}

Two or more variables that are not stationary at level but stationary during differentiation, then there will likely be a cointegration between those variables (Engle and Granger, 1987). The cointegration test is done to see that there is no long-term relationship between variables (Widarjono, 2013). In this research using Johansen cointegration test to see the number of cointegration (rank of cointegration) between variables. Hypothesis testing used trace statistical tests and maximum eigenvalue. Johansen's cointegration test formulation in this research follows:

$\Delta \mathrm{P}_{\mathrm{t}}=\sum_{\mathrm{j}=1}^{\mathrm{p}-1} \Gamma_{\mathrm{i}} \Delta \mathrm{P}_{\mathrm{t}-1}+\Pi \mathrm{P}_{\mathrm{t}-\mathrm{k}}+\beta \mathrm{X}_{\mathrm{t}}+\mathrm{e}_{\mathrm{t}}$

where:

$\mathrm{P}_{\mathrm{t}} \quad$ : vector $\mathrm{k}$ from variable non-stationary, $\mathrm{I}(1)$

$\mathrm{X}_{\mathrm{t}} \quad$ : vector $\mathrm{d}$ from variable deterministick

$\mathrm{e}_{\mathrm{t}} \quad$ : vektor inovation

ח : $: \sum_{\mathrm{i}=1}^{\mathrm{p}} \mathrm{A}_{\mathrm{i}}-1$

Г $\quad:-\sum_{\mathrm{j}=\mathrm{i}+1}^{\mathrm{p}} \mathrm{A}_{\mathrm{j}}$

There is no cointegration between variables based on test likelihood ratio (LR). Hypothesis testing based on the following conditions:

$H_{o}=$ variable not cointegration $(\mathrm{LR}$ value < critical value $5 \%$ )

$H_{1}=$ variable are cointegrastion $(\mathrm{LR}$ value > critical value $5 \%$

d. Granger Causality Test
The test of Granger Causality using to see the reciprocal relationship between Indonesian cocoa beans price with cocoa price in New York Board of Tarde (NYBOT), India, USA, and Malaysia. In VAR model each variable has the same opportunity to become an endogenous or exogenous variable (Widarjono, 2013). There is no causality tested through test $\mathrm{F}$ based on the probability value of each model.

e. Vector Autoregression (VAR)/Vector Error Correction Model (VECM)

VAR model that use to analysis variables is not stationary at level level but the stationary in same level of differentiation, and there is no cointegration between those variables is VAR in difference (VARD) approach. While the VECM model is used when variables are not stationary at level but stationary at the same differentiation level and there is a cointegration. Model VECM measures presence of price adjustment mechanisms to return to a state of balance (Engle and Granger, 1987). The VARD/VECM Model used in this research as follows:

$$
\begin{aligned}
\mathrm{PI}_{\mathrm{t}}= & \alpha_{0}+\sum_{\mathrm{i}=1}^{\mathrm{p}} \alpha_{1} \mathrm{PI}_{\mathrm{t}-1}+\sum_{\mathrm{i}=1}^{\mathrm{p}} \alpha_{2} \mathrm{PN}_{\mathrm{t}-1}+ \\
& \sum_{\mathrm{i}=1}^{\mathrm{p}} \alpha_{3} \mathrm{PA}_{\mathrm{t}-1}+\sum_{\mathrm{i}=1}^{\mathrm{p}} \alpha_{4} \mathrm{PM}_{\mathrm{t}-1}+ \\
& \sum_{\mathrm{i}=1}^{\mathrm{p}} \alpha_{\mathrm{i}} \mathrm{PIND}_{\mathrm{t}-1}+\varepsilon_{\mathrm{it}} \\
\mathrm{PN}_{\mathrm{t}}= & \alpha_{0}+\sum_{\mathrm{i}=1}^{\mathrm{p}} \alpha_{1} \mathrm{PI}_{\mathrm{t}-1}+\sum_{\mathrm{i}=1}^{\mathrm{p}} \alpha_{2} \mathrm{PN}_{\mathrm{t}-1}+ \\
& \sum_{\mathrm{i}=1}^{\mathrm{p}} \alpha_{3} \mathrm{PA}_{\mathrm{t}-1}+\sum_{\mathrm{i}=1}^{\mathrm{p}} \alpha_{4} \mathrm{PM}_{\mathrm{t}-1}+ \\
& \sum_{\mathrm{i}=1}^{\mathrm{p}} \alpha_{\mathrm{i}} \mathrm{PIND}_{\mathrm{t}-1}+\varepsilon_{\mathrm{it}}
\end{aligned}
$$

$$
\begin{aligned}
\mathrm{PA}_{\mathrm{t}}= & \alpha_{0}+\sum_{\mathrm{i}=1}^{\mathrm{p}} \alpha_{1} \mathrm{PI}_{\mathrm{t}-1}+\sum_{\mathrm{i}=1}^{\mathrm{p}} \alpha_{2} \mathrm{PN}_{\mathrm{t}-1}+ \\
& \sum_{\mathrm{i}=1}^{\mathrm{p}} \alpha_{3} \mathrm{PA}_{\mathrm{t}-1}+\sum_{\mathrm{i}=1}^{\mathrm{p}} \alpha_{4} \mathrm{PM}_{\mathrm{t}-1}+ \\
& \sum_{\mathrm{i}=1}^{\mathrm{p}} \alpha_{\mathrm{i}} \mathrm{PIND}_{\mathrm{t}-1}+\varepsilon_{\mathrm{it}}
\end{aligned}
$$

$$
\begin{aligned}
\mathrm{PM}_{\mathrm{t}}= & \alpha_{0}+\sum_{\mathrm{i}=1}^{\mathrm{p}} \alpha_{1} \mathrm{PI}_{\mathrm{t}-1}+\sum_{\mathrm{i}=1}^{\mathrm{p}} \alpha_{2} \mathrm{PN}_{\mathrm{t}-1}+ \\
& \sum_{\mathrm{i}=1}^{\mathrm{p}} \alpha_{3} \mathrm{PA}_{\mathrm{t}-1}+\sum_{\mathrm{i}=1}^{\mathrm{p}} \alpha_{4} \mathrm{PM}_{\mathrm{t}-1}+ \\
& \sum_{\mathrm{i}=1}^{\mathrm{p}} \alpha_{\mathrm{i}} \mathrm{PIND}_{\mathrm{t}-1}+\varepsilon_{\mathrm{it}}
\end{aligned}
$$

$$
\begin{aligned}
\operatorname{PIND}_{\mathrm{t}}= & \alpha_{0}+\sum_{\mathrm{i}=1}^{\mathrm{p}} \alpha_{1} \mathrm{PI}_{\mathrm{t}-1}+\sum_{\mathrm{i}=1}^{\mathrm{p}} \alpha_{2} \mathrm{PN}_{\mathrm{t}-1}+ \\
& \sum_{\mathrm{i}=1}^{\mathrm{p}} \alpha_{3} \mathrm{PA}_{\mathrm{t}-1}+\sum_{\mathrm{i}=1}^{\mathrm{p}} \alpha_{4} \mathrm{PM}_{\mathrm{t}-1}+ \\
& \sum_{\mathrm{i}=1}^{\mathrm{p}} \alpha_{\mathrm{i}} \mathrm{PIND}_{\mathrm{t}-1}+\varepsilon_{\mathrm{it}}
\end{aligned}
$$

VARD/VECM analysis on research illustrates the short-term dynamic balance relationship in the model. In addition to the short term balance on the VECM model can also be used to see the long term balance. Price relations between markets are separated spatially despite the long-term balance found, but there is a deviation from the short-term balance relationship. The shortterm balance relationship may vary significantly (Widarjono, 2013) 
f. Impulse Response Function

Impulse Response Function (IRF) analysis is using to view the dynamic structure of variable responses to model shocks (Enders, 1995). IRF analysis will show how the endogenous variables react to the interference in the variables themselves and other variables. IRF analysis is required in the VAR/VECM estimate because individually the coefficient in the model is difficult to interpret. The use of the impulse response function analysis will help researchers track shocks in several future periods (Widarjono, 2013)

\section{g. Variance Decomposition}

VAR model also has the ability to see the cause of interference from a variable, using a test forecast error decomposition of variance or often called variance decomposition (Widarjono, 2013). Variance decomposition in VAR estimation will illustrate the dynamic system of the model. Variance decomposition analysis is used to measure the approximate proportion of the impact of a variable change if it experiences shock or variable changes itself over a certain period. If shock of variable to-i directly affect not only the variables themselves, but will be forwarded to the other variables contained in the model.

Analysis price efficiency of Indonesia cocoa beans in spot market Makassar using GARCH approach. The stages of price efficiency analysis using the GARCH model are as follows:

\section{a. Stationarity Test}

Data price of cocoa beans in the spot market of Makassar tested its presence with an Augmented Dickey-Fuller (ADF) test, so that the resulting regression is spurious regression) (Widarjono, 2013). The rule of testing is done by looking at the $\mathrm{ADF}_{\text {statistics }}$ and $\mathrm{ADF}_{\text {critis. }}$ if value of $\mathrm{ADF}_{\text {statistics }}>\mathrm{ADF}_{\text {critis }}$, then the data does not contain the unit root or is already stationary, otherwise $\mathrm{ADF}_{\text {statistics }}>\mathrm{ADF}_{\text {critis }}$, then the data is not stationary.

\section{b. ACF and PACF Correlogram Test}

Before estimation of GARCH model, it first detected the presence of autocorrelation and heteroskedasticity (ARCH) using Correlogram ACF and PACF tests. Test by looking at the Q-stat value and the drastically decreased chart (spiked). Model determined based on observation lag that does not contain autocorrelation element (Widarjono, 2013). Detection of ARCH elements using the following hypothesis:
$\mathrm{H}_{0}$ : time series data does not contain ARCH ( probability value> ctitis value)

$\mathrm{H}_{1}$ : time series data contain ARCH ( probability value < critis value)

c. GARCH Test

GARCH model is a development of $\mathrm{ARCH}$ model, where in this model is used to look at variant variable error not only depends on previous residual period but also the previous period residual variant (Bollerslev, 1986). In general, GARCH model is GARCH (p, q) expressed in the following equation:

$$
\begin{aligned}
\sigma_{t}^{2}= & \alpha_{0}+\alpha_{1} e_{t-1}^{2}+\cdots+\alpha_{p} \sigma_{t-p}^{2}+\lambda_{1} \sigma_{t-1}^{2}+ \\
& \cdots+\alpha_{q} \sigma_{t-q}^{2}
\end{aligned}
$$

Where $\mathrm{p}$ indicates the element of $\mathrm{ARCH}$ and $\mathrm{q}$ indicates the element GARCH. GARCH models are estimated using the maximum likelihood method. Testing the market efficiency hypothesis using the GARCH model as follows:

$\mathrm{H}_{0}$ : there is no relation variant residual $t-1$ period with $t$ period

$\mathrm{H}_{1}$ : there is relation variant residual $\mathrm{t}-1$ period with $\mathrm{t}$ period

Rules of testing:

1). If $\mathrm{p}$-value $<0,05$, then reject $\mathrm{H}_{0}$ that means market is efficient

2). If $\mathrm{p}$-value $>0,05$, then accept $\mathrm{H}_{0}$ that means market not efficient

\section{RESULTS AND DISCUSSION}

Results of the integration analysis price of Indonesia cocoa beans with importing countries (USA, Malaysia, and India), and world market (New York Board of Trade) using the VAR/VECM model approach as follows:

\section{a. Stationarity Data \\ Based on stationary test using Augmented} Diclkey-Fuller (ADF) is obtained results that price of cocoa bean in Indonesia, USA, Malaysia, India and New York are not stationary at level, but stationary at first difference All variable is not significant at $5 \%$ in level, means that variable have unit root and not stationary. When analysis still using the data, will result of estimation parameter is spurious regression. To overcome this, using ADF test in first difference variable. At first difference level indicate that the five tested variable already stationary. It is viewed from the value of ADF_statistic > ADF_critical value, and the probability value is smaller than 0.05 . Based on the station test can be concluded that all the stationary variables in the same order is the order I (1), so that 
the estimation result of the model will be freed from spurious regression. The result of ADF test analysis is presented in Table 1 as follows.

Table 1. Result of ADF Test level and first difference

\begin{tabular}{|c|c|c|c|c|c|c|}
\hline \multicolumn{4}{|c|}{ ADF-level } & \multicolumn{3}{|c|}{ ADF-first difference } \\
\hline Pasar & Critical Value $5 \%$ & t-stat & Prob & Critical Value $5 \%$ & t-stat & Prob \\
\hline Indonesia & $-2,9126$ & $-2,9125$ & 0,2112 & $-2,9126$ & $-14,829$ & $0,000 * *$ \\
\hline USA & $-2,9126$ & $-1,8535$ & 0,5868 & $-2,9126$ & 10,202 & $\begin{array}{l}0,00 \\
0 * *\end{array}$ \\
\hline Malaysia & $-2,9117$ & $-2,3120$ & 0,1717 & $-2,9126$ & $\begin{array}{r}- \\
8,8722 \\
\end{array}$ & $\begin{array}{r}0,00 \\
0 * * \\
\end{array}$ \\
\hline India & $-2,9135$ & $-2,6253$ & 0,0939 & $-2,9135$ & $\begin{array}{r}- \\
11,764\end{array}$ & $\begin{array}{l}0,00 \\
0 * *\end{array}$ \\
\hline New York & $-2,9117$ & $-0,2945$ & 0,9190 & $-2,9126$ & $\begin{array}{r}- \\
5,3213\end{array}$ & $\begin{array}{l}0,00 \\
0 * *\end{array}$ \\
\hline
\end{tabular}

Source: Secondary data processed, 2019

Description: *=significant at $1 \%, * *=$ significant at $5 \%, * * *=$ significant at $10 \%$

\section{b. Lag Optimal Determination}

Based on the optimal test lag using the Akaike Information criteria (AIC) criterion, it obtained lag 2 as the optimal lag in the VAR model. Optimal LAG occurs if the criteria value used has the least absolute value. All of the variable in the model remain constan and affect each other not only the current period, but those variables are interconnected in the previous two periods. Lagoptimal test results are presented in Table 2 as follows

Table 2. Result Lag-Optimal

\begin{tabular}{cccccc}
\hline Lag & LR & FPE & AIC & SC & HQ \\
\hline 0 & NA & $3,64 \mathrm{e}-10$ & $-7,545424$ & $-7,362940$ & $-7,474856$ \\
\hline 1 & 194,0964 & $1,73 \mathrm{e}-11$ & $-10,59748$ & $-9,502576^{* *}$ & $-10,17407 * *$ \\
\hline 2 & $49,10723^{* *}$ & $1,44 \mathrm{e}-11^{* *}$ & $-10,80447^{* *}$ & $-8,797134$ & $-10,02822$ \\
\hline 3 & 30,14758 & $1,75 \mathrm{e}-11$ & $-10,66839$ & $-7,748634$ & $-9,539297$ \\
\hline 4 & 18,81810 & $2,80 \mathrm{e}-11$ & $-10,31277$ & $-6,489592$ & $-9,830838$ \\
\hline 5 & 31,33325 & $2,90 \mathrm{e}-11$ & $-10,48414$ & $-5,739534$ & $-8,649363$ \\
\hline
\end{tabular}

Source: Secondary data processed, 2019

c. Johansen Cointegration Test

Based on the trace value stastic and MaxEigenvalue, price of Indonesia cocoa bean with price cocoa bean of USA and Malaysia has no cointegration. Value of trace stastistic and maxeigenvalue prices in both markets are less than the $5 \%$ critical value, as well as the probability value greater than $\alpha 5 \%$ (table 3 ). No cointegration price of Indonesia cocoa beans with USA and Malaysia shows that in long term there is no balance relationship between prices in both markets. No cointegration means price of Indonesia cocoa bean with the USA and Malaysia is not integrated, it is harm to Indonesia as producer of cocoa because price changes in the USA and Malaysia is not transmitted to Indonesia. No price transmission indicates a failure of the Law of One Price (LOP), where the price signals and information is transmitted evenly so that movement of price between different markets will be same (Flacker and Goodwin, 2001).

Table 3. Result Johansen Cointegration Test

\begin{tabular}{|c|c|c|c|c|c|c|}
\hline \multicolumn{4}{|c|}{ Trace Test } & \multicolumn{3}{|c|}{ Max-eigenvalue Test } \\
\hline Cointegration & Trace stat & Critical value & Prob & Max-Eigenvalue & Critical value & Prob \\
\hline \multicolumn{4}{|c|}{ Indonesia with USA } & \multicolumn{3}{|c|}{ Indonesia with USA } \\
\hline None & 12,4226 & 20,2618 & 0,4117 & 6,8123 & 15,8921 & 0,6923 \\
\hline At Most 1 & 5,6102 & 9,1645 & 0,2231 & 5,6102 & 9,1645 & 0,2231 \\
\hline \multicolumn{4}{|c|}{ Indonesia with Malaysia } & \multicolumn{3}{|c|}{ Indonesia with Malaysia } \\
\hline None & 13,3156 & 20,2618 & 0,3391 & 9,1072 & 15,8921 & 0,4224 \\
\hline At Most 1 & 4,2084 & 9,1645 & 0,3820 & 4,2084 & 9,1645 & 0,3820 \\
\hline \multicolumn{4}{|c|}{ Indonesia with India } & \multicolumn{3}{|c|}{ Indonesia with India } \\
\hline
\end{tabular}




\begin{tabular}{|c|c|c|c|c|c|c|}
\hline None & $37,2272 * *$ & 25,8721 & 0,0013 & $26,1135^{* * *}$ & 19,3870 & 0,0045 \\
\hline At Most 1 & 11,1137 & 12,5179 & 0,0848 & 11,1137 & 12,5179 & 0,0848 \\
\hline \multicolumn{4}{|c|}{ Indonesia with terminal New York } & \multicolumn{3}{|c|}{ Indonesia with terminal New York } \\
\hline None & $26,6617 * *$ & 25,8721 & 0,0398 & 26,6617 & 25,8721 & 0,1808 \\
\hline At Most 1 & 11,4198 & 12,5179 & 0,0757 & 11,4198 & 12,5179 & 0,0757 \\
\hline
\end{tabular}

Source: Secondary data processed, 2019

Different results of Johansen cointegration test between prices of cocoa bean Indonesia with India Ana New York Board of Trade. Based on value of trace statistic and max-eigenvalue at rank $=0$ (none), there is two cointegration between price of cocoa beans Indonesia and India. While the price of Indonesian cocoa beans with New York there is one cointegration based on trace statistical value at $r a n k=0$. The existence of cointegration indicates that the price of cocoa beans between Indonesia and India, and New York has a long-term balance in the relationship.

Markets that have relationship long-term balance in the market between integrated. Changes in the market price of reference (India and New York), will transmitted to market followers (Indonesia). This is to indicate a price change information interrelated properly, and discrepancy of price is relatively small so that fluctuation of price also relatively small. In this research conducted Awal et al (2009), in an integrated market price movements on the same product will be the same, although it is marketed in different places. In international trade two spatially integrated market if the price for the commodity continues to trade between the two countries (after adjusting for exchange rate and transaction cost) are the same, then in accordance with the principles of the Law of One Price (LOP) (Miljkovic, 1999).

\section{d. Granger Causality Test}

Granger causality test is used to determine the influential market and which affect the relationship between the price of cocoa bean at different location. Based on these test, there is a one-way causality between the price of cocoa bean between Indonesia and India, and between price of Indonesian cocoa bean with New York. From value of the F-statistic and probability of Indonesia cocoa price are influenced by price of cocoa bean in India, but India cocoa bean price are not influenced by price of Indonesia cocoa. Between price of cocoa bean Indonesia and New York showed that the price of cocoa in New York influenced by price of Indonesia cocoa at 5\% significan level. This indicates that Indonesia as the country's third largest cocoa producer could affect the price of cocoa on the world market that is New York Board of Trade. This is contra with previous research doing Ariyo (2010), in his research price of Indonesia cocoa beans can't influence price of cocoa bean in world market because bargaining position Indonesia is weak. While the price of Indonesian cocoa beans with the USA and Malaysia showed no causality which means that variables such price independently or no effect each other. Granger causality test results are presented in Table 4 as follow.

Table 4. Result Granger Causality Test

\begin{tabular}{llll}
\hline Hipotesis nol & Obs & F-stat & Prob \\
\hline USA does not Granger Cause Indonesia & \multirow{2}{*}{58} & 0,024 & 0,975 \\
Indonesia does not Granger Cause USA & \multirow{2}{*}{5} & 0,990 & 0,378 \\
\hline Malaysia does not Granger Cause Indonesia & \multirow{2}{*}{5} & 2,325 & 0,723 \\
Indonesia does not Granger cause Malaysia & \multirow{2}{*}{5} & 1,312 & 0,105 \\
\hline India does not Granger Cause Indonesia & \multirow{2}{*}{58} & 3,980 & 0,277 \\
Indonesia does not Granger Cause India & \multirow{2}{*}{4,363} & $0,024^{* *}$ \\
\hline New York does not Granger Cause Indonesia & 0,337 & 0,714 \\
Indonesia does not Granger Cause New York & & &
\end{tabular}

Source: Secondary data processed, 2019

e. Estimate Vector Autorregrresive (VAR) Model

Price of cocoa bean Indonesia and USA are no cointegration indicate no long-term relationship between these markets. Although these two

Agricultural Socio-Economics Journal markets are not integrated in the long term, but in the short term can be evaluated through VAR approach. Model estimation is VAR in Difference (VARD). In VARD used in cases of non stationary time series data at the current level, but stationary 
at the same differentiation and are not cointegrated. In this research price of Indonesia cocoa bean with price of USA cocoa bean not integrated.

Change of price cocoa bean in Indonesia and USA are significantly influenced by price itself only in the period of the previous month at -0.54 and -0.34 in significance level $5 \%$. Price formation of cocoa bean in Indonesia, when an increase in the price of US\$ 1 in the previous period will cause a deterioration in the current price of US\$ 0.54. Price formation of cocoa bean in USA if price increases of US $\$ 1$ in one month previous period cause decrease in the current price of US\$ 0.34 (table 5). While other variable did not affect the price of cocoa bean Indonesia and USA. There is no effect of changes in prices of cocoa beans USA to price changes of Indonesia cocoa does not indicate the transmission of prices and there is no short-term integration. Bushara and Abdelmahmoed (2015) states that the market is not integrated in the long term or short term may be caused by the distance between distant markets. The results of model estimation VARD between the price of Indonesian cocoa bean with the USA are presented in Table 5 as follow.

Table 5. Result VARD Model

\begin{tabular}{|c|c|c|}
\hline \multirow{2}{*}{$\begin{array}{l}\text { Independent } \\
\text { Variable }\end{array}$} & \multicolumn{2}{|c|}{ Dependent Variable } \\
\hline & DIndonesia & DUSA \\
\hline \multirow{2}{*}{ Dindonesia (-1) } & $-0,544 * * *$ & 0,062 \\
\hline & {$[-3,11]$} & {$[0,337]$} \\
\hline \multirow{2}{*}{ Dindonesia (-2) } & 0,005 & 0,147 \\
\hline & {$[0,034]$} & {$[0,823]$} \\
\hline \multirow{2}{*}{ DUSA $(-1)$} & 0,017 & $-0,334 * *$ \\
\hline & {$[0,102]$} & {$[-1,88]$} \\
\hline \multirow{2}{*}{ DUSA $(-2)$} & 0,174 & $-0,066$ \\
\hline & {$[1,071]$} & {$[-0,386]$} \\
\hline \multirow{2}{*}{$\mathrm{C}$} & 0,007 & $-0,0007$ \\
\hline & {$[0,561]$} & {$[-0,013]$} \\
\hline R-squared & 0,373 & 0,104 \\
\hline
\end{tabular}

Source: Secondary data processed, 2019

VARD model estimation between price of cocoa beans Indonesia with Malaysia show that, Indonesia cocoa price changes influence by price itsself in previous period one month and two month by 1.01 at the level of $1 \%$ and 0.03 at the level of $10 \%$. If price of Indonesia cocoa bean increased by US\$ 1 at one month previous period will decreased current price of US\$ 1.01 and if increased US\$ 1 at two-month previous period will decreased current price of US\$ 0.03 (Table 6 ).

Table 6. Results Estimas Model VARD

\begin{tabular}{lcc}
\hline \multirow{2}{*}{$\begin{array}{l}\text { Independent } \\
\text { variables }\end{array}$} & \multicolumn{2}{c}{ Dependent variables } \\
\cline { 2 - 3 } DIndonesia (-1) & $\begin{array}{c}-1.014 * * * \\
{[-5,636]}\end{array}$ & $\begin{array}{c}-0.741 * * * \\
{[-3,280]}\end{array}$ \\
\hline DIndonesia (-2) & $\begin{array}{c}-0.031^{*} \\
{[-0,162]}\end{array}$ & $\begin{array}{c}-0.215 \\
{[-0,873]}\end{array}$ \\
\hline DMalaysia (-1) & $\begin{array}{c}0.572 * * * \\
{[3,912]}\end{array}$ & $\begin{array}{c}0.120 \\
{[0,654]}\end{array}$ \\
\hline DMalaysia (-2) & $\begin{array}{c}0.226 * * \\
{[1,436]}\end{array}$ & $\begin{array}{c}0.275 * \\
{[1,388]}\end{array}$ \\
\hline C & -0.001 & .0132 \\
& {$[-0,148]$} & {$[-0,912]$} \\
\hline R-squared & 0.504 & 0.321 \\
\hline \multicolumn{2}{c}{ Source: Secondary data is processed, 2019 }
\end{tabular}

Source: Secondary data is processed, 2019

Additionally Indonesia cocoa price change was also influenced by the price of cocoa in Malaysia during one month previous period by 0.57 and 0.22 at two months. This means that if there is an increase price of cocoa in Malaysia US\$ 1 at one month previous in advance will increase price in Indonesia currently at US\$ 0.57. Meanwhile, if price of cocoa in Malaysia increased by US\$ 1 at previous two-month, causing price of Indonesia cocoa bean increased by US $\$ 0.22$ today. While the price of cocoa in Malaysia is influenced by the price itself in the previous two-month period earlier. If there is increase price of cocoa beans in Malaysia US\$ 1 at previous two months would increase current price by US\$ 0.27. Furthermore price of cocoa beans Malaysia also affected the price of cocoa beans in Indonesia during previous month. This means that if the price of cocoa beans in Indonesia increased at one month previous by US\$ 1, it will cause decrease price of cocoa in Malaysia amounted to US\$ 0.74 (Table 6). The influence of price changes in Malaysia cocoa beans to price changes in Indonesia cocoa beans, and otherwise. This indicates price transmission between markets. The price transmission shows that an integrated market in the short term. Bernal et al (2003) states that the adjacent distance markets will increase trade flows so that market will be integrated.

\section{f. Estimate Vector Error Correction Model (VECM) \\ VECM test continues step for $\mathrm{c}$ integration} test, if found cointegration between variables at the same level of orders is first difference. Results of VECM cocoa price in Indonesia with cocoa bean price in India shows that correction in price 
Indonesia and India is significant at the $1 \%$ level, statistical value are -0.152 and 0.229 . Value of coefficient ECT Indonesia is 0,152 show that to return equilibrium short-term need time one month to adjustment. Indonesian cocoa price changes only affected by its price at one month previously. If there is an increase in the price of $U \$ 1$ in one month previous period will increase the price of cocoa bean currently US\$ 0.48 (Table 7).

Table 7. Results VECM Model

\begin{tabular}{lcc}
\hline \multirow{2}{*}{$\begin{array}{l}\text { Independent } \\
\text { variables }\end{array}$} & \multicolumn{2}{c}{ Dependent variables } \\
\cline { 2 - 3 } ECT $_{1}$ & $-0.152 * * *$ & DIndia \\
\hline \multirow{2}{*}{ DIndonesia (-1) } & $0,483 * * *$ & $0.229 * * *$ \\
& {$[-3,687]$} & {$[2,616]$} \\
\hline \multirow{2}{*}{ DIndonesia (-2) } & -0.067 & -0.218 \\
& {$[-0,521]$} & {$[-0,045]$} \\
\hline \multirow{2}{*}{ DIndia (-1) } & 0.079 & -0.0847 \\
& {$[-1,060]$} & {$[-1,620]$} \\
\hline \multirow{2}{*}{ DIndia (-2) } & -0.017 & $-0.311 * * *$ \\
& {$[-0,276]$} & {$[-3,11]$} \\
\hline \multirow{2}{*}{ C } & 0,005 & -0.004 \\
& {$[0,451]$} & {$[-0,243]$} \\
\hline R-squared & 0.457 & 0.446 \\
\hline \multicolumn{2}{c}{ Source: Secondary data processed, 2019 }
\end{tabular}

Value coefficient ECT of price cocoa bean in India is 0.229 at level of $1 \%$, it means price adjustment in India needs two month to adjust equilibrium price in market. Change price of cocoa bean in India only influence price it's at one and two months previous each -0.193 and -0.311 . Increasing price cocoa beans of India US\$ 1 at one month previously caused a decrease in current price of US\$ 0,139. Meanwhile, if there is an increase of US\$ 1 in the previous two-month, it will result in the decrease in current price of US\$ 0.22 (Table 7). Nothing effect of price in Indian to change Indonesia prices, and otherwise showed no short-term market integration between two markets. In international trade, which is not only Indonesia cocoa producers to allow price of cocoa bean in India is influenced by prices of other producers. Ghosh (2003) states that integrated relationship of price behavior will form relevant price signals and transmitted evenly. If there is no integration between market indicates information market participants are not same.

VECM model estimation also applied to price of cocoa beans in Indonesian and New York. Based on result of Johansen cointegration test, it can obtained that price in Indonesia and New York on the long-term equilibrium relationship. Price of Indonesia cocoa bean and New York is integrated in the long term. Short-term equilibrium relationship seen through value ECT in estimated VECM. ECT coefficient value of Indonesia cocoa significant price is -0.366 , indicating that variable in the model is independent (price of Indonesia cocoa previous one-month period) influence adjustment mechanism in short-term. Change of price cocoa bean in Indonesian only affected by its price in the period of the previous month are -0.42 . This mean if price of cocoan bean in Indonesia during increase $U \$ 1$ in the previous period cause decreasing current price of US\$ 0.42 (Table 8).

ECT coefficient value in New York not significant and only -0.042. Negative and smaller value indicates that short-term price adjustment mechanism in New York market away from equilibrium market. It is also supported by Rsquared value is lower it just $16 \%$. Price of cocoa bean in New York can only be explained by price of cocoa bean in Indonesian during one month and two months previous period, and price in New York itself at one and two months previous by $16 \%$, the rest is explained by other variables outside the model. New York is center of world cocoa trade, so that Indonesia opens the sole exporter of cocoa in this market.

Table 8. VECM Model Estimation Results

\begin{tabular}{ccc}
\hline \multirow{2}{*}{$\begin{array}{l}\text { Independent } \\
\text { variables }\end{array}$} & \multicolumn{2}{c}{ Dependent variables } \\
\cline { 2 - 3 } \multicolumn{1}{c}{ ECT $_{1}$} & $\begin{array}{c}\text { DIndonesia } \\
\text { DIndonesia (-1) }\end{array}$ & DNew York \\
\hline \multirow{2}{*}{ DIndonesia (-2) } & $-0.422 * * *$ & -0.042 \\
& {$[-3,096]$} & {$[-0,740]$} \\
\hline \multirow{2}{*}{ DNew York (-1) } & 0.0788 & 0.061 \\
& {$[0,619]$} & {$[2,028]$} \\
\hline \multirow{2}{*}{ DNew York (-2) } & -0.094 & $0.281 * *$ \\
& {$[-0,068]$} & {$[1,882]$} \\
\hline \multirow{2}{*}{ C } & 0,006 & -0.150 \\
& {$[0,562]$} & {$[-1,006]$} \\
\hline R-squared & 0.504 & 0.002 \\
\hline Source: Secondary & data process & 0.161 \\
\hline
\end{tabular}

Source: Secondary data processed, 2019

Change price of cocoa beans in New York because of influence price of cocoa bean in Indonesia during previous two months. Formation of New York prices, if price of cocoa bean in Indonesia increasing at previous two months were 
US\$1, will make price of cocoa bean in New York increasing by US\$ 0.13 . Beside changes of price cocoa bean in New York also affected by price itself in one month previous period. This means that when price of cocoa beans in New York increased US\$ 1 on one month previous period, will cause an increase in current price of U\$ $\$ 0.28$. Despite influence price of cocoa bean in Indonesia to price in New York, but negative ECT value and $\mathrm{R}$-square indicates that short-term price adjustment mechanism away from market equilibrium price. So the price of cocoa bean between Indonesia and New York are not integrated short term.

\section{g. Impulse Response Function}

Indonesian cocoa price response to shock of prices cocoa bean in USA begins to respond at second period with negative response. Given negative response due to changes price of cocoa beans in USA has no effect, and price in both markets are not related. There is accordance with results of cointegration test and VARD model estimation. Different response shown by changes price of cocoa bean in Malaysia against Indonesia cocoa price changes are positive responses ranged from 0.008 to 0.01 . Small Indonesian cocoa price response to changes price of cocoa bean in Malaysia showed no price equilibrium relationship between both markets.

Price of cocoa bean in Indonesia response to shocks of price cocoa beans in India and New York immediately responded in first period. Responses indicated as a result of changes in prices on both markets with increasing prices of cocoa bean in Indonesia. Response stable in the period to five, which means that the effects of shocks that would be lost in the period to five, and than price will return to market equilibrium.

h. Variance Decomposition

Price of cocoa bean in Indonesia at first months, if there are shocks of price cocoa bean in USA and Malaysia, the variability of price is only explained by effect of its price changes. Until predictions for 10 months ahead, price of cocoa bean in Indonesia variability explained by its price to $99.71 \%$, while price shocks in USA only explain $0.23 \%$. While the cocoa bean price shocks in Malaysia only explain change of price cocoa bean in Indonesia to $2,68 \%$. This indicates that longterm price shocks will not effect price of cocoa bean in Indonesia.
Variability price of cocoa bean in Indonesia when price shocks in India and New York for 10 months predictions are influenced by price in India to $34.22 \%$ and price in New York to $53.20 \%$. This indicates that prices in New York and India can explain variability of price of cocoa beans in Indonesia. This indicates a long-term equilibrium relationship between price of cocoa bean in Indonesia with India and New York.

The results analysis of efficiency of Indonesia cocoa prices in spot market Makassar showed efficiency-weak form. Current price reflects the information of price in the past. The complete results analysis efficiency price of cocoa bean in Indonesia with GARCH approach as follows:

\section{a. Stationarity test}

Cocoa bean prices in spot market Makassar expressed in terms of return as changes in value of the gain or loss will be accepted. Analysis efficiency in $\mathrm{t}$ market, expected benefits should be equal to zero (Fama, 1970). Result stationary to for monthly price of cocoa bean in spot market Makassar had been stationary in the current level. ValueADF $_{\text {statistik }}(-14,82765) \geq$ $\operatorname{ADF}_{\text {critical value }}(-2,912631)$, while tprobability value $0,0000<\alpha(0,05)$. Based on this results hypothesis is rejected, which means time series data spot market price of cocoa beans do not contain unit root, so that the data is stationary.

b. Test Correlogram ACF and PACF

ACF and PACF correlogram test used to detect autokroleasi problem. If found autocorrelation detection test should be performed ARCH element. The test results coorelogram ACF and PACF on the return price of cocoa beans showed Q-stat value is high and probability value is less than $5 \%$. This means that time series data contained elements of ARCH.

ACF value decreases exponentially, while value of PACF spike at lag 1 , so tentative models used are AR 1. Model AR (1) detection of residual white noise in the AR model using correlogram Qstatistic. The test based on probability value throughout the lag has been greater than $\alpha(0.05)$, so that residual model AR (1) is white noise. The model is back tested whether there is an element of ARCH ARCH-LM test as follows: 
Table 9. Results ARCH-LM Model AR (1)

\begin{tabular}{llll}
\hline \multicolumn{2}{c}{ Hetreoskedasticity Test: ARCH } & & \\
\hline F-statistic & 0.673724 & Prob. F (24.9) & .7901 \\
\hline Obs * R-squared & $21.84237 * *$ & Prob. Chi-Square (24) & $0.5887 * *$ \\
\hline
\end{tabular}

Source: Secondary data processed, 2019

Based on the calculated value $x^{2}(\mathrm{Obs} * \mathrm{R})$ is equal to 21.84 with probability 0.5887 greater than $\alpha$ (0.05). This indicates that the constant residual variance in other words, the model does not contain elements of ARCH.

\section{c. GARCH}

GARCH test used to see if variance shock variable influenced by residual and residual variance previous period. Statistically coefficient AR (1) is significant, which means the return of the price of cocoa on the spot market in the markets influenced by return of price previous period. While residual squares (ARCH) previous period is not significant, probability value of $\operatorname{RESID}(-1)^{\wedge} 2$ are 0.0810 is greater than $\alpha(0.05)$. Different with residual coefficients, coefficient of residual variance previous period are significant, because probability value 0.0000 is smaller than $\alpha(0.05)$. Means residual variance (GARCH) previous period influence error prediction of return affects price of cocoa bean in Indonesia. GARCH test results are presented in Table 10 as follow.

Table 10. Estimation Results Return Price of Cocoa Beans with GARCH

\begin{tabular}{lllll}
\hline Variables & Coefficient & \multicolumn{1}{c}{ Std. Error } & z-statistics & Prob. \\
\hline $\mathrm{C}$ & 0.018301 & $3,85 \mathrm{E}-05$ & 475.143 & 0.0000 \\
\hline $\mathrm{AR}(1)$ & -0.332270 & 0.082721 & -4.01675 & $0.0001 * *$ \\
\hline \multicolumn{5}{c}{ Variance Equation } \\
\hline $\mathrm{C}$ & $-7,58 \mathrm{E}-05$ & 0.000177 & -0.42783 & 0.6688 \\
\hline Resid $(-1)^{\wedge} 2$ & -0.165611 & 0.94919 & -1.74475 & 0.0810 \\
\hline GARCH (-1) & 1.233850 & 0.153762 & 8.024410 & $0.0000 * *$ \\
\hline R-squared & 0.259120 & Akaike information criterion & -2.2714 \\
\hline Log likelihood & 70.87151 & Schwarz criterion & -2.0938 \\
\hline Durbin-Watson stat & 2.432096 & Hannan-Quinn criter & -2.2022 \\
\hline
\end{tabular}

Source: Secondary data processed, 2019

Test on return price of cocoa bean in spot market Makassar with parametric test there is a rejection of the hypothesis $\mathrm{H}_{0}$, This means that there is relationship between return price previous period with current period, which residual variance previous period significantly affect current price prediction. So that market is efficient, because it can predict price by collecting information price in the past and residual variance in the past. In accordance with Anindita and Baladina (2017), if the price can be predicted well, then the market efficiently. Such uncertainty risk premium price on spot market Makassar, making it an efficient market weak-form because current prices reflect pricing information in the past. Sathye (2006) the existence of price uncertainty will cause prices to fluctuate, so that manufacturers would have difficulty predicting the price.

\section{CONCLUSION}

Based on the research that has been done, it can be concluded as follows:

Based on analysis of market integration between price of Indonesian cocoa is integrated in the short term with price of cocoa bean in Malaysia. In addition, in long term price of cocoabean in Indonesia is integrated with price of cocoa bean in India. This condition occurs information indicates price change from the consumer point (Malaysia and India) is transmitted to the point of producers (Indonesia). While the price of Indonesian beans with the USA there are no integration, where changes in prices in the USA are not transmitted to Indonesia. distances 
also be the cause of inter-market integration does not occur, so that the market is segmented.

Indonesian cocoa bean prices in world market (New York Board of Trade) is integrated in the long term, while in the short term are not integrated. No integration in short term due to other like-biggest cocoa producers Ivory Coast, Ghana, Nigeria and Cameroon which may affect the formation of prices of cocoa beans at the New York Board of Trade.

Formation of Indonesian cocoa prices in the spot market Makassar showed weak-form market efficiency. Current price reflects price information in the past. This indicates that the price of cocoa on the market can be predicted with good in Makassar by using price information in the past. The implication of market participants do not face risk premium in the form of price volatility or price fluctuations will hurt market players especially cocoa producer.

\section{REFERENCES}

Anindita, R and Baladina, N. 2017. Products Marketing of Agricultural Products. Andi, Yogyakarta

Ariyoso. 2010. Integration of Market and Factors Influencing the Indonesian Cocoa price. Thesis: Bogor Agricultural University, Bogor

Awal., Et al. 2009. Spatial Price Integration and Efficiency of Export Markets Pricing Level: A Case of Bangladeh exportable Fresh Vegetables Markets. Bangladesh Agriculture Ecomics Journal: 1-16

Bernal, LP, Thilmany, DD, and Loureiro, ML 2003. An Empirical Analysis of Market Integration and Efficiency for US Fresh Tomato Markets. Journal of agricultural and resouce Economics 28 (3): 435-450

Bollerslev T. 1986. Generalized Autoregressive Heteroscedasticity with Estimate of the Variance of UK Inflation. Econometrica, Vol. 31

Bushara, MOA and Abdelmahmod, MKA. 2015. Efficiency of Selected Sudanese Cattle Markets: Multivariate Cointegration Approach (1995-2011). International Journal of Economics and Management Sciences Vol. 47

Enders, Walter. 1995. Applied Econometric Time Series. John Wiley and Sons, New York
Engle, R. And Granger, C. 1987. Cointegration and Error Correction: Representation, Estimation, and Testing. Journal Econometrica 55: 251-276

Fama, Eugene, F. 1970. Efficient Capital Markets: A Review of Theory and Empirical Work. Journal of Finace 25 (2): 383-417

Fackler, P and Goodwin, B. 2001. Spatial Price Analysis. Handbook of Agriculture Economics, Vol 1: 972-1018, Elsievier Science, Amsterdam

Ghosh, M. 2003. Spatial Integration of Wheat Markets in India: Evidence from Cointegration Test. Oxford Development Studies, Vol 31 \# 2

International Cocoa Organization (ICCO). 2014. The Cocoa Market Situation. Fourth Meeting Economics Committee. London

Lence, S and Falk, B. 2005. Cointegration, merket Integration, adn Market Efficiency. Journal of International Money and Finance. 24: 873-890

Miljkovic, D. 1999. The Law of One price in International Trade: A Critical Review. Review Agriculture Economics 21: 12639

Sathye, M. 2006. The US Coffee 'C' futures: Some Results From Test of Cointegration and GARCH. Journal Economtrics and International Development. 6 (3): 131136

United Nations Comtrade. 2017. Monthly Price of Cocoa Beans. line:https://comtrade.un.org.)

Widarjono, A. 2018. Econometrics: Introduction and Application Accompanied Free Eviews. UPP STIM YKPN Yogyakart 
